\title{
移動ロボットのための遡及的現在位置推定法 処理時間を要する外界センサデータの利用一
}

前山祥 一*1 大矢晃 久*2 油田信 一*2

\author{
Retroactive Positioning for a Mobile Robot \\ - To Cope with Time Consuming External Sensors-
}

Shoichi Maeyama*1 ${ }^{* 1}$ Akihisa Ohya ${ }^{* 2}$ and Shin'ichi Yuta*2

\begin{abstract}
We propose a position estimation method for non-stop navigation of an autonomous mobile robot. The proposed method is based on the maximum likelihood estimation. To cope with the time delay in the sensor data process, we introduce a retroactive positioning data fusion method. The proposed technique is implemented on our small size autonomous mobile robot. An experimental result is shown, in which the robot could navigate itself without stopping even when it takes several seconds of processing time to recognize landmark from external sensor data.
\end{abstract}

Key Words: Mobile Robot Navigation, Sensor Fusion, Positional Uncertainty, Landmark Recognition

\section{1.はじめに}

本論文では，移動ロボットが走行中に,「過去の自分の位置が 間違っていると気が付いたとき，現在の自分の位置をどう考え 直せばよいか.」について議論する。

移動ロボットが目的地への到達や地図の生成などを目的とし た行動を行う場合，自分の現在位置を正しく認識することは非 常に重要である。ここでは，移動ロボットがデッドレコニング とランドマーク認識の融合によって現在位置を推定する場合を 考える.この方法を用いて移動ロボットの位置を推定する研究 は，これまでも多く行われ，その有効性が確認されてきた [1] 〜 [5]. ただし，この方法ではランドマークの認識処理に時間を 要すると, その処理結果から得られるロボットの位置は, すで に過去の位置の情報になっているという問題が起こる。なぜな ら，ランドマークの認識処理中に，デッドレコニングにより現 在位置が更新されてしまうからである、ロボットがゆっくり走 行したり，停止したりする場合を除き，ランドマークの認識処 理に要する時間が無視できないときに通常の走行速度を維持す るには, ランドマークの認識に要する時間を考虑した現在位置 の推定が必要である.

障害物の検出を行う場合，センサの処理はリアルタイムでな ければならない。しかし，位置の推定を行う場合には，センサ の処理は必ずしもリアルタイムである必要はない.むしろ，推 定位置の誤差が回復不可能なくらい大きく累積する前に，その

\footnotetext{
原稿受付 1997 年 2 月 24 日

*1 筑波大学大学院博士課程工学研究科

*2筑波大学電子情報工学系

${ }^{* 1}$ Doctoral Program, University of Tsukuba

*2 Institute of Information Science and Electronics, University of Tsukuba
}

誤差をキャンセルできればよい，現在位置の推定のためのラン ドマーク認識においては, 誤認識を防ぐことが何よりも重要で あり，そのために処理に時間を要する場合が少なくない。この ような場合にもロボットが通常速度を保ったまま現在位置の推 定が行えるようにするには，過去のロボットの位置の推定結果 をうまく現在位置の推定に利用できる方法があればよい.

センサデータの処理に時間を要することは本質的な問題で ありながら、これまでの移動ロボットの位置推定の研究におい て，丁寧に扱われた例はあまりない，Kosaka らは，拡張カル マン・フィルタを用いた視覚に基づく移動ロボットの屋内ナビ ゲーションの研究において同様な問題に直面した。 そこで，画 像処理中に実効された走行コマンドのヒストリを保存しておき, 処理結果が得られた時点で，まず画像処理を始めた時刻の位置 を修正し，次に保持しておいた走行コマンドのヒストリを使っ て現在位置を修正する方法を提案した [6]. これに対して, 本論 文では，デッドレコニングによって連続的に位置を推定する枠 組の上に，認識処理に時間を要するセンサデータを間欠的に利 用して，より確からしい位置を推定する方法を構築した．本方 法でも，センサデー夕処理後に自己位置を遡及的に修正するこ とをべースとしているが, 本方法は, 走行制御の方法に依存し ない独立した位置推定サブシステムとして実装でき，また，複 数のセンサが並列にデー夕を処理する場合にも，適用可能であ るという特徴を有する。本論文では，本手法の原理とその実験 結果について述べる。

\section{2. 問 題 設 定}

本章では, 本論文で取り扱う問題の前提条件を整理し, 提案 する手法の基本的な考え方を述べる.

ロボットは, ロボット本体の速度・角速度を測定する内界セ 
ンサを持ち, サンプリング時間間隔 $\tau$ ごとに, それらの測定値 を用いたデッドレコニングによる位置推定を行えるものとする. ここでは, $\tau$ ごとに行われる 1 回のデッドレコニングのための 計算を 1 ステップの計算と呼ぶことにする．また，ランドマー クの観測などにより間欠的にロボットの位置に関する外界セン サデータが得られ，そのデータを使ってデッドレコニングによ る位置が修正できるものとする，本論文では，以上の枠組のな かで, ランドマークの認識処理に要する時間が無視できない場 合に, ロボットを通常走行速度に保ったまま走行させる方法に ついて考える.

ランドマークの認識処理に $n$ ステップ要する場合,つまり, 処理時間が $n \tau$ である場合の基本的な処理の流れは, Fig. 1 と

Fig. 2 に示すように,

(1) 時刻 $t_{0}$ にランドマークを観測し, 認識処理を開始 (Fig. 1 と Fig. 2 の (A))

(2) $n \tau$ 間, 動きながらランドマークの認識処理 (Fig. 1 と Fig. 2 の (B))

(3) 時刻 $t_{0}+n \tau$ のとき, 認識処理が終了, 現在の位置情報を 再考 (Fig. 1 と Fig. 2 の (C))

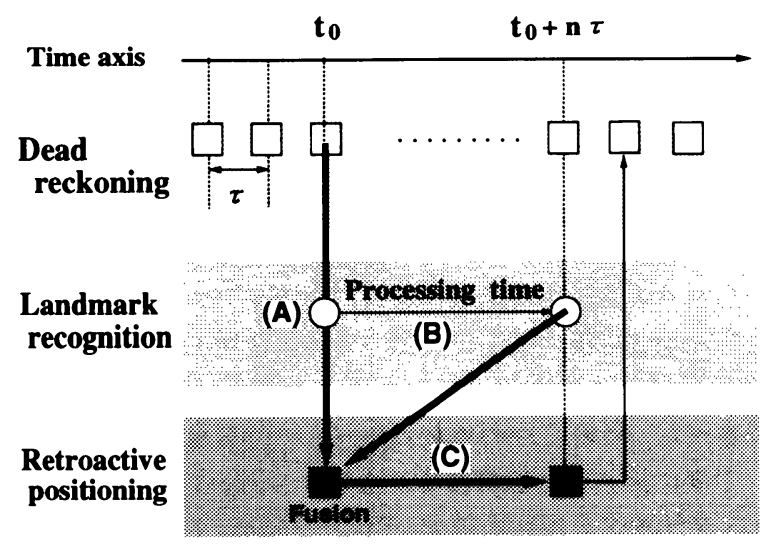

Fig. 1 The time diagram of retroactive positioning data fusion and re-estimation of positional uncertainty at current time. (A) Landmark observation. (B) Process of a landmark info. (C) Re-estimation of the current position.
という手順になる，ただし，移動ロボットは，二次元平面とみ なせる路面を移動するものとする，また，“位置”とは，二次 元平面上の位置だけでなくロボットの進行方位も含み, “位置 情報”とは，推定位置だけでなく，誤差の共分散行列により表 される不確実性の推定量も含むものとする. Fig. 2 中の楕円は, 位置の誤差の共分散行列から計算される誤差楕円 [1] [3] であり， ロボットの存在確率が等しい位置を結んだものである.

ここで, 時刻 $t_{0}$ における位置情報と時刻 $t_{0}$ から時刻 $t_{0}+n \tau$ までの位置情報の増分をすべて保持しておき，まずランドマー クの認識結果から得られる位置情報を用いて時刻 $t_{0}$ における 位置情報を修正した後, 時刻 $t_{0}$ から時刻 $t_{0}+n \tau$ までの位置 計算をもう一度行えば原理的には遡及的に現在位置情報が修正 できる.しかし，この計算を何ら工夫をせず行うと， $n$ ステッ プ分の計算時間と記憶容量が必要となり現実的でなくなってし まう。

以降, 3 章では, ランドマーク認識処理中のデッドレコニン グによる位置情報の増分について解析し，ランドマークの認識 結果が得られた時に現在位置を再考するために必要なデータに ついて検討する，4 章では，3 章の解析結果に基づいて，遡及 的位置推定法の公式を導く.

\section{3. ランドマークの認識処理時間を考慮した 推定位置情報の解析}

\section{1 ランドマーク認識処理中のデッドレコニングによる位 置情報の增分}

本節では, 時刻 $t_{0}$ の位置情報と時刻 $t_{0}+n \tau$ の位置情報の 二つの位置情報の関係, すなわち, $n$ ステップ間のデッドレコ ニングによる位置情報の増分を求める.

まず，時刻 $t_{0}$ において，ロボットの並進速度 $v\left[t_{0}\right]$, ロボッ ト本体の角速度 $\omega\left[t_{0}\right]$ が得られた場合における, デッドレコニ ングによる位置とその誤差の不確実性の表現方法, および, そ れらの推定値の更新方法について述べる.

ロボットの二次元平面上の位置 $\left(x\left[t_{0}\right], y\left[t_{0}\right]\right)$ とロボットの方 位 $\theta\left[t_{0}\right]$ をベクトルにより,

$$
\mathbf{P}\left[t_{0}\right]=\left[\begin{array}{lll}
x\left[t_{0}\right] & y\left[t_{0}\right] & \left.\theta\left[t_{0}\right]\right]^{T}
\end{array}\right.
$$

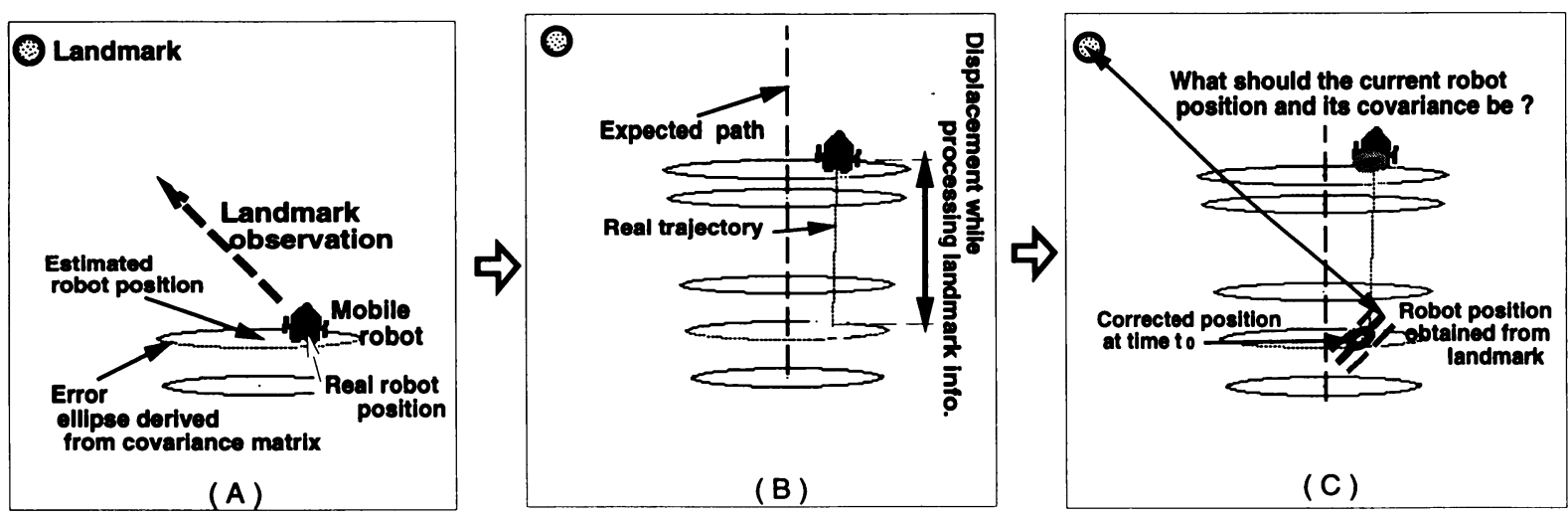

Fig. 2 Conceptual figures of retroactive positioning data fusion and re-estimation of positional uncertainty at current time. (A) Landmark observation. (B) Process of a landmark info. (C) Re-estimation of the current position. 
で表す.ここで，“ $T ”$ は転置を表す。サンプリング時間 $\tau$ 後 の位置は, ロボットの並進速度 $v\left[t_{0}\right]$ とロボット本体の角速度 $\omega\left[t_{0}\right]$ から,

$$
\mathbf{P}\left[t_{0}+\tau\right]=\mathbf{P}\left[t_{0}\right]+\tau\left(\begin{array}{c}
v\left[t_{0}\right] \cos \left(\theta\left[t_{0}\right]\right) \\
v\left[t_{0}\right] \sin \left(\theta\left[t_{0}\right]\right) \\
\omega\left[t_{0}\right]
\end{array}\right)+\tau \mathbf{n}\left[t_{0}\right]
$$

で計算される．ここで, $\mathbf{n}\left[t_{0}\right]$ は，量子化や計算によって生じる 誤差である. $v\left[t_{0}\right]$ と $\omega\left[t_{0}\right]$ をまとめて, ベクトル $\mathrm{V}\left[t_{0}\right]$ で表 す. 今, $\hat{\mathbf{P}}\left[t_{0}\right]$ を $\mathbf{P}\left[t_{0}\right]$ の推定値, $\Delta \mathbf{P}\left[t_{0}\right]$ をその誤差, $\hat{\mathbf{V}}\left[t_{0}\right]$ を $\mathbf{V}\left[t_{0}\right]$ の測定値, $\Delta \mathbf{V}\left[t_{0}\right]$ をその誤差とおき，

$$
f\left(\mathbf{P}\left[t_{0}\right], \mathbf{V}\left[t_{0}\right]\right)=\mathbf{P}\left[t_{0}\right]+\tau\left(\begin{array}{c}
v\left[t_{0}\right] \cos \left(\theta\left[t_{0}\right]\right) \\
v\left[t_{0}\right] \sin \left(\theta\left[t_{0}\right]\right) \\
\omega\left[t_{0}\right]
\end{array}\right)
$$

としたとき, $\Delta \mathbf{P}\left[t_{0}\right], \Delta \mathbf{V}\left[t_{0}\right]$ と $\mathbf{n}\left[t_{0}\right]$ の期待値が 0 とみなせる ならば, 時刻 $t_{0}+\tau$ における位置の推定値は,

$$
\hat{\mathbf{P}}\left[t_{0}+\tau\right]=f\left(\hat{\mathbf{P}}\left[t_{0}\right], \hat{\mathbf{V}}\left[t_{0}\right]\right)
$$

で与えられる.このとき, $\Delta \mathbf{P}\left[t_{0}\right], \Delta \mathbf{V}\left[t_{0}\right]$ と $\mathbf{n}\left[t_{0}\right]$ が小さいと みなせると，

$$
\begin{aligned}
\mathbf{P}\left[t_{0}+\tau\right]= & f\left(\mathbf{P}\left[t_{0}\right], \mathbf{V}\left[t_{0}\right]\right)+\tau \mathbf{n}\left[t_{0}\right] \\
= & f\left(\hat{\mathbf{P}}\left[t_{0}\right]+\Delta \mathbf{P}\left[t_{0}\right], \hat{\mathbf{V}}\left[t_{0}\right]+\Delta \mathbf{V}\left[t_{0}\right]\right)+\tau \mathbf{n}\left[t_{0}\right] \\
\simeq & f\left(\hat{\mathbf{P}}\left[t_{0}\right], \hat{\mathbf{V}}\left[t_{0}\right]\right)+\mathbf{j}\left[t_{0}\right] \Delta \mathbf{P}\left[t_{0}\right]+\mathbf{k}\left[t_{0}\right] \Delta \mathbf{V}\left[t_{0}\right] \\
& +\tau \mathbf{n}\left[t_{0}\right] \\
= & \hat{\mathbf{P}}\left[t_{0}+\tau\right]+\Delta \mathbf{P}\left[t_{0}+\tau\right]
\end{aligned}
$$

と表される.ここで,

$$
\begin{aligned}
& \mathbf{j}(t)=\left.\frac{\partial f(\mathbf{P}(t), \mathbf{V}(t))}{\partial \mathbf{P}(t)}\right|_{\hat{\mathbf{P}}_{(t)}, \hat{\mathbf{V}}_{(t)}} \\
& \mathbf{k}(t)=\left.\frac{\partial f(\mathbf{P}(t), \mathbf{V}(t))}{\partial \mathbf{V}(t)}\right|_{\hat{\mathbf{P}}_{(t)}, \hat{\mathbf{V}}_{(t)}}
\end{aligned}
$$

である．したがって，推定位置 $\hat{\mathbf{P}}\left[t_{0}\right]$ の誤差は，サンプリング 時間間隔 $\tau$ ごとに

$$
\begin{aligned}
\Delta \mathbf{P}\left[t_{0}+\tau\right]= & \mathbf{j}\left[t_{0}\right] \Delta \mathbf{P}\left[t_{0}\right]+\mathbf{k}\left[t_{0}\right] \Delta \mathbf{V}\left[t_{0}\right] \\
& +\tau \mathbf{n}\left[t_{0}\right]
\end{aligned}
$$

と変化する．また, $\Delta \mathbf{P}\left[t_{0}\right]$ の共分散行列は,

$$
\begin{aligned}
\boldsymbol{\Sigma}_{P}\left[t_{0}\right] & =E\left(\Delta \mathbf{P}\left[t_{0}\right] \Delta \mathbf{P}\left[t_{0}\right]^{T}\right) \\
& =\left[\begin{array}{lll}
\sigma_{x}\left[t_{0}\right]^{2} & \sigma_{x y}\left[t_{0}\right] & \sigma_{x \theta}\left[t_{0}\right] \\
\sigma_{x y}\left[t_{0}\right] & \sigma_{y}\left[t_{0}\right]^{2} & \sigma_{y \theta}\left[t_{0}\right] \\
\sigma_{x \theta}\left[t_{0}\right] & \sigma_{y \theta}\left[t_{0}\right] & \sigma_{\theta}\left[t_{0}\right]^{2}
\end{array}\right]
\end{aligned}
$$

で与えられる．この值は, 誤差 $\Delta \mathbf{P}\left[t_{0}\right]$ の大きさの指標である. 共分散行列 $\boldsymbol{\Sigma}_{P}\left[t_{0}\right]$ は, $\Delta \mathbf{P}\left[t_{0}\right]$ と $\Delta \mathbf{V}\left[t_{0}\right]$ と $\mathbf{n}\left[t_{0}\right]$ が，互いに
無相関であるとみなせる場合, 式 (8) より, サンプリング時間 間隔 $\tau$ ごとに,

$$
\begin{aligned}
\boldsymbol{\Sigma}_{P}\left[t_{0}+\tau\right]= & \mathbf{j}\left[t_{0}\right] \boldsymbol{\Sigma}_{P}\left[t_{0}\right] \mathbf{j}\left[t_{0}\right]^{T}+\mathbf{k}\left[t_{0}\right] \boldsymbol{\Sigma}_{V}\left[t_{0}\right] \mathbf{k}\left[t_{0}\right]^{T} \\
& +\tau^{2} \boldsymbol{\Sigma}_{N}\left[t_{0}\right]
\end{aligned}
$$

で更新される。ここで，

$$
\begin{aligned}
& \boldsymbol{\Sigma}_{V}\left[t_{0}\right]=E\left(\Delta \mathbf{V}\left[t_{0}\right] \Delta \mathbf{V}\left[t_{0}\right]^{T}\right) \\
& \boldsymbol{\Sigma}_{N}\left[t_{0}\right]=E\left(\mathbf{n}\left[t_{0}\right] \mathbf{n}[t]^{T}\right)
\end{aligned}
$$

である。

次に, 式 (2) と式 (10) の渐化式を $t_{0}+n \tau$ と $t_{0}+(n-1) \tau$ の関係式から順々に $t_{0}$ まで時間を遡っていき, $n$ サンプリン グ離れた推定位置とその誤差の共分散行列の関係を求めると, 推定位置は,

$$
\hat{\mathbf{P}}\left[t_{0}+n \tau\right]=\hat{\mathbf{P}}\left[t_{0}\right]+\hat{\mathbf{P}}_{n}
$$

となる.ここで,

$$
\hat{\mathbf{P}}_{n}=\sum_{i=0}^{n-1} \tau\left(\begin{array}{c}
v\left[t_{0}+i \tau\right] \cos \left(\theta\left[t_{0}+i \tau\right]\right) \\
v\left[t_{0}+i \tau\right] \sin \left(\theta\left[t_{0}+i \tau\right]\right) \\
\omega\left[t_{0}+i \tau\right]
\end{array}\right)
$$

である。そして，その誤差の共分散行列は，

$$
\boldsymbol{\Sigma}_{P}\left[t_{0}+n \tau\right]=\mathbf{J}_{n} \boldsymbol{\Sigma}_{P}\left[t_{0}\right] \mathbf{J}_{n}^{T}+\mathbf{K}_{n}+\mathbf{N}_{n}
$$

となる．ここで,

$$
\begin{aligned}
\mathbf{J}_{n} & =\prod_{i=n-1}^{0} \mathbf{j}_{i}=\mathbf{j}_{n-1} \mathbf{j}_{n-2} \cdots \mathbf{j}_{1} \mathbf{j}_{0} \\
\mathbf{K}_{n} & =\sum_{l=0}^{n-1}\left\{\prod_{i=n}^{l+1} \mathbf{j}_{i} \cdot \mathbf{k}_{l} \mathbf{\Sigma}_{V}\left(\prod_{i=n}^{l+1} \mathbf{j}_{i} \cdot \mathbf{k}_{l}\right)^{T}\right\} \\
\mathbf{N}_{n} & =\sum_{l=0}^{n-1}\left\{\prod_{i=n}^{l+1} \mathbf{j}_{i} \tau^{2} \mathbf{\Sigma}_{n}\left(\prod_{i=n}^{l+1} \mathbf{j}_{i}\right)^{T}\right\}
\end{aligned}
$$

であり, $\mathbf{j}_{i}$ は, $\mathbf{j}\left[t_{0}+i \tau\right]$ を意味し, $\mathbf{k}_{i}$ は, $\mathbf{k}\left[t_{0}+i \tau\right]$ を意味す る.ただし， $i=n$ のときの $\mathbf{j}_{i}$ ，つまり $\mathbf{j}_{n}$ は単位行列とする.

\section{2 ランドマークの認識処理の開始時刻における位置情報} の修正

ここでは, 時刻 $t_{0}+n \tau$ においてランドマークの認識処理が 終わったときの, ランドマークの認識結果に基づいた時刻 $t_{0}$ の位置情報の修正方法について述べる.

ランドマークの認識結果から得られる情報をべクトルを用 いて

$$
\mathbf{s}=\left[\begin{array}{llll}
s_{1} & s_{2} & \ldots & s_{n}
\end{array}\right]^{T}
$$

で表し，その誤差の共分散行列を $\boldsymbol{\Sigma}_{s}$ で表す．また，ランド マークの認識結果から得られるロボットの位置の拘束関係を,

$$
\mathbf{g}\left[\mathbf{P}\left[t_{0}\right], \mathbf{s}\right]=\mathbf{0}_{m \times 1}
$$


で表す. 式 $(20)$ は, $\hat{\mathbf{P}}\left[t_{0}\right]$ の推定位置に含まれる誤差が小さ いとみなせる場合, $\hat{\mathbf{P}}\left[t_{0}\right]$ まわりで線形化でき，

$$
\left.\mathbf{g}\left[\hat{\mathbf{P}}\left[t_{0}\right]\right], \hat{\mathbf{s}}\right]+\mathbf{j}_{p}\left(\mathbf{P}\left[t_{0}\right]-\left[\hat{\mathbf{P}}\left[t_{0}\right]\right]\right)+\mathbf{j}_{s} \Delta \mathbf{s}=\mathbf{0}_{m \times 1}
$$

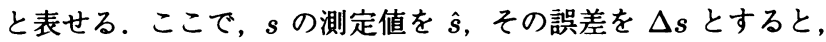
$\mathbf{j}_{p}$ と $\mathbf{j}_{s}$ は,

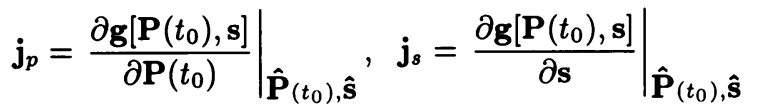

で与えられる。

式（21）の両辺を $\mathbf{j}_{p}$ の各行ベクトルで正规化すると

$$
\mathbf{J}_{p}\left(\mathbf{P}\left[t_{0}\right]-\hat{\mathbf{P}}\left[t_{0}\right]\right)=-\mathbf{G}-\mathbf{J}_{s} \Delta \mathbf{s}
$$

となり,ランドマークの認識結果によって拘束される位置情 報は，

$$
\begin{aligned}
\hat{\mathbf{P}}_{s u} & =\mathbf{J}_{p}\left(\hat{\mathbf{P}}_{s}-\hat{\mathbf{P}}\left[t_{0}\right]\right) \\
& =-\mathbf{G} \\
\boldsymbol{\Sigma}_{s u} & =\mathbf{J}_{s} \boldsymbol{\Sigma}_{\boldsymbol{s}} \mathbf{J}_{s}^{T}
\end{aligned}
$$

で表せる.

次に, $\hat{\mathbf{P}}\left[t_{0}\right]$ とランドマークの認識結果から得られたロボッ トの位置に関する情報とを融合するために， $\mathbf{J}_{p}$ を用いて $\hat{\mathbf{P}}\left[t_{0}\right]$ を $\hat{\mathbf{P}}_{s u}$ と同じ座標系に変換する.

$$
\begin{aligned}
\hat{\mathbf{P}}_{u}\left[t_{0}\right] & =0 \\
\boldsymbol{\Sigma}_{u}\left[t_{0}\right] & =\mathbf{J}_{p} \boldsymbol{\Sigma}_{p}\left[t_{0}\right] \mathbf{J}_{p}^{T}
\end{aligned}
$$

ここで, $\hat{\mathbf{P}}_{u}\left[t_{0}\right]$ は, 座標変換後の $\hat{\mathbf{P}}\left[t_{0}\right]$ であり, $\boldsymbol{\Sigma}_{u}\left[t_{0}\right]$ は, そ の誤差の共分散行列である.

そのとき，その最尤推定量は，

$$
\begin{aligned}
\hat{\mathbf{P}}_{f u} & =\boldsymbol{\Sigma}_{f u} \boldsymbol{\Sigma}_{s u}^{-1} \hat{\mathbf{P}}_{s u} \\
\boldsymbol{\Sigma}_{f u} & =\left(\boldsymbol{\Sigma}_{u}\left[t_{0}\right]^{-1}+\boldsymbol{\Sigma}_{s u}^{-1}\right)^{-1}
\end{aligned}
$$

で表される。

最後に式（28）（29）を元の $x y \theta$ の座標系に戻すと,

$$
\begin{aligned}
\hat{\mathbf{P}}_{f}\left[t_{0}\right] & =\hat{\mathbf{P}}\left[t_{0}\right]+\mathbf{J}_{p}^{-1} \hat{\mathbf{P}}_{f u} \\
& =\hat{\mathbf{P}}\left[t_{0}\right]+\boldsymbol{\Sigma}_{f} \mathbf{J}_{p}^{T} \boldsymbol{\Sigma}_{s u}^{-1} \hat{\mathbf{P}}_{s u} \\
\boldsymbol{\Sigma}_{f}\left[t_{0}\right] & =\mathbf{J}_{p}^{-1} \boldsymbol{\Sigma}_{f u}\left(\mathbf{J}_{p}^{T}\right)^{-1} \\
& =\left\{\boldsymbol{\Sigma}_{p}\left[t_{0}\right]^{-1}+\mathbf{J}_{p}^{T} \boldsymbol{\Sigma}_{s u}^{-1} \mathbf{J}_{p}\right\}^{-1}
\end{aligned}
$$

となる。したがって，センサデータの処理開始時のロボットの 位置 $\hat{\mathbf{P}}\left[t_{0}\right]$ は，式（30）より， $\boldsymbol{\Sigma}_{f} \mathbf{J}_{p}^{T} \boldsymbol{\Sigma}_{s u}^{-1} \hat{\mathbf{P}}_{s u}$ だけ修正される。 また，修正後の誤差の共分散行列は，式（31）で与えられる。

\section{3 現在位罪情報の再計策}

本節では, 時刻 $t_{0}$ の位置情報が, 前節の公式で修正された ときに, 現在時刻 $t_{0}+n \tau$ の位置を再計算する方法を導く.

ここで，単に式 (13) の $\hat{\mathbf{P}}\left[t_{0}\right]$ を式 $(30)$ の $\hat{\mathbf{P}}_{f}\left[t_{0}\right] に$ にま た, 式 (15)の $\boldsymbol{\Sigma}_{p}\left[t_{0}\right]$ を式（31）の $\boldsymbol{\Sigma}_{f}\left[t_{0}\right]$ に置き换えること を考えてみる。この置き換えたものを逆行列の補助定理 [7]を 用いて式変形すると, ランドマークの認識処理の結果が得られ た後の現在時刻 $t_{0}+n \tau$ の位置情報は,

$$
\begin{aligned}
\hat{\mathbf{P}}_{f}\left[t_{0}+n \tau\right]= & \hat{\mathbf{P}}\left[t_{0}\right]+\hat{\mathbf{P}}_{n}+\boldsymbol{\Sigma}_{f} \mathbf{J}_{p}^{T} \boldsymbol{\Sigma}_{s u}^{-1} \hat{\mathbf{P}}_{s u} \\
\boldsymbol{\Sigma}_{f}\left[t_{0}+n \tau\right]= & \mathbf{J}_{n} \boldsymbol{\Sigma}_{f}\left[t_{0}\right] \mathbf{J}_{n}^{T}+\mathbf{K}_{n}+\mathbf{N}_{n} \\
= & \mathbf{J}_{n}\left\{\boldsymbol{\Sigma}_{p}\left[t_{0}\right]^{-1}+\mathbf{J}_{p}^{T} \boldsymbol{\Sigma}_{s u}^{-1} \mathbf{J}_{p}\right\}^{-1} \mathbf{J}_{n}^{T} \\
& +\mathbf{K}_{n}+\mathbf{N}_{n} \\
= & \mathbf{J}_{n} \boldsymbol{\Sigma}_{p}\left[t_{0}\right] \mathbf{J}_{n}^{T}+\mathbf{K}_{n}+\mathbf{N}_{n}-\mathbf{J}_{n} \boldsymbol{\Sigma}_{p}\left[t_{0}\right] \mathbf{J}_{p}^{T} \\
& \times\left(\mathbf{J}_{p} \boldsymbol{\Sigma}_{p}\left[t_{0}\right] \mathbf{J}_{p}^{T}+\boldsymbol{\Sigma}_{s u}\right)^{-1} \mathbf{J}_{p} \boldsymbol{\Sigma}_{p}\left[t_{0}\right] \mathbf{J}_{n}^{T}
\end{aligned}
$$

と書ける. 式 (32) の第 1 項と第 2 項の和は, まさしく, ラン ドマークの観測結果を利用する前の現在位畳であり, 式 (33) の第 1 項から第 3 項までの和は，まさしくランドマークの観 测結果を利用する前の現在位置の誤差の分散であり, 一見, 現 在の位置情報とランドマークの認識結果による位圈情報の修正 分は，分離できるかにみえる。しかしながら，これらの式中の $\hat{\mathbf{P}}_{n}, \mathbf{J}_{n}, \mathbf{K}_{n}, \mathbf{N}_{n}$ の各項は, 時刻 $t_{0}$ のロボットの方位 $\theta\left[t_{0}\right]$ に 依存するため, $\theta\left[t_{0}\right]$ が $\theta\left[t_{0}\right]+\alpha$ に修正されたとき，実際には， これらの項も修正されなければならない.

これらの項の修正は，回転行列

$$
\mathbf{R}(\alpha)=\left(\begin{array}{ccc}
\cos (\alpha) & -\sin (\alpha) & 0 \\
\sin (\alpha) & \cos (\alpha) & 0 \\
0 & 0 & 1
\end{array}\right)
$$

を使って以下のように計算できる. まず, $\hat{\mathbf{P}}_{n}$ は, $\hat{\mathbf{P}}_{n}^{\prime}=\mathbf{R}(\alpha) \hat{\mathbf{P}}_{n}$ で修正される。次に， $\mathbf{J}_{n}$ の修正值 $\mathbf{J}^{\prime}{ }_{n}$ は， $\mathbf{J}_{n}$ の 3 列目の列べ クトルを $\mathbf{R}(\alpha) \mathbf{J}_{n 3}$ で貫き換えることで得られる。 また, $\mathbf{K}_{n}$ は, $\mathbf{K}_{n}^{\prime}=\mathbf{R}(\alpha) \mathbf{K}_{n} \mathbf{R}(\alpha)^{T}$ で修正できる。なお， $\mathbf{N}_{n}$ は $\mathbf{R}(\alpha)$ を使っても修正できないが, $\mathbf{N}_{n}$ は小さい値なので, 後の公式 の導出の便宜上, $\mathbf{N}^{\prime}{ }_{n} \simeq \mathbf{R}(\alpha) \mathbf{N}_{n} \mathbf{R}(\alpha)^{T}$ で置き換えておく.

\section{4. 遡及的現在位置推定法の公式}

前章の解析結果から，ランドマークの認識処理の開始時点で の位置情報である $\hat{\mathbf{P}}\left[t_{0}\right]$ が $\hat{\mathbf{P}}_{f}\left[t_{0}\right]$ に, $\boldsymbol{\Sigma}_{P}\left[t_{0}\right]$ が $\boldsymbol{\Sigma}_{f}\left[t_{0}\right]$ に修 正されたとき，処理の終了時点での位置情報である $\hat{\mathbf{P}}_{f}\left[t_{0}+n \tau\right]$ $\boldsymbol{\Sigma}_{f}\left[t_{0}+n \tau\right]$ を得る遡及的現在位置推定法の公式は,

$$
\begin{aligned}
& \hat{\mathbf{P}}_{f}\left[t_{0}+n \tau\right]=\hat{\mathbf{P}}_{f}\left[t_{0}\right]+\hat{\mathbf{P}}_{n}^{\prime}, \\
& \boldsymbol{\Sigma}_{f}\left[t_{0}+n \tau\right]=\mathbf{J}^{\prime}{ }_{n} \boldsymbol{\Sigma}_{f}\left[t_{0}\right] \mathbf{J}^{\prime T}{ }_{n}+\mathbf{K}^{\prime}{ }_{n}+\mathbf{N}^{\prime}{ }_{n} .
\end{aligned}
$$

で与えられる。

ここで, $\hat{\mathbf{P}}_{n}^{\prime}$ は, $\mathbf{R}(\alpha) \hat{\mathbf{P}}_{n}$ であり, $\mathbf{J}_{n}^{\prime}$ は $\mathbf{J}_{n}$ の 3 列目の列 ベクトルを $\mathbf{R}(\alpha) \mathbf{J}_{n 3}$ で置き換えたものであり， 


$$
\mathbf{K}_{n}^{\prime}+\mathbf{N}^{\prime}{ }_{n}=\mathbf{R}(\alpha)\left\{\mathbf{K}_{n}+\mathbf{N}_{n}\right\} \mathbf{R}(\alpha)^{T}
$$

である.ただし， $\alpha$ はロボット方位 $\theta\left[t_{0}\right]$ の修正量であり， $\mathbf{R}(\alpha)$ は式（34）で与えられる回転行列である。 また, $\hat{\mathbf{P}}_{n}, \mathbf{J}_{n}, \mathbf{K}_{n}$, $\mathbf{N}_{n}$ は, ランドマークの認識処理中のデッドレコニングによる 位置情報の增分で式（14）と式（16）～式（18）で与えられる.

この公式を適用するために保存しなければならないデッドレ コニングよる位置情報は,

$$
\hat{\mathbf{P}}\left[t_{0}\right], \boldsymbol{\Sigma}_{P}\left[t_{0}\right], \hat{\mathbf{P}}_{n}, \mathbf{J}_{n}
$$

の四つとなる.ここで， $\mathbf{K}_{n}+\mathbf{N}_{n}$ については，式（15）を用 いて, $\boldsymbol{\Sigma}_{P}\left[t_{0}\right], \boldsymbol{\Sigma}_{P}\left[t_{0}+n \tau\right], \mathbf{J}_{n}$ とから逆算できることを考虑 した.

\section{5. 複数のランドマークの並列認識が 可能な場合への拡張}

本章では, 複数のランドマークの認識処理を並列に認識でき る場合について議論する。

もし, 複数のランドマークの認識处理が時間軸上で重なり合 わなければ，前章で述べた計算方法は，そのまま用いることが できる。しかし，もし複数のランドマークの認識処理が時間軸 上で重なり合う場合, その複数のランドマークの認識結果を有 効に使って現在位置情報を計算するには, 計算の順序を考虑し なければならない. 例えば, 二つのランドマークの認識处理が 時間軸上で重なりあった場合を考えると，Fig. 3 に示すような 2 種類の場合が考えられる。ここで， $S_{i}$ は，時刻 $T_{i}$ に処理を 開始し時刻 $T_{i}^{\prime}$ に処理を終了するランドマークの認識処理を表 す. CASE 1 は，二つのランドマークの認識処理が部分的に重 なりあった場合である. CASE 2 は，二つのランドマークの認 識処理が完全に重なりあった場合である。いずれの場合も問題 は，過去の位置情報を修正した後で通常どおりに直接現在位置 情報を修正すると，その前にすでに処理を終えていたほうのラ ンドマークによる修正の意味がなくなってしまうことである.

この問題を解決するために, 過去のある時刻から現在時刻ま での位置情報の増分を, ランドマークの認識处理の開始ごとに

\section{[ CASE 1]}

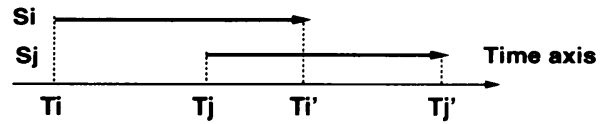

\section{[ CASE 2]}

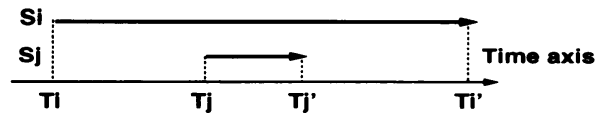

Start to process

\section{Finish processing}

Fig. 3 Overlapping of two landmark recognition processes on time axis. $\left(S_{i}, S_{j}\right.$ : Processes for landmark recognition, $T_{i}, T_{j}$ : Time when the processes are started, $T_{i}^{\prime}, T_{j}^{\prime}$ : Time when the processes are finished.)
分割して保持しておくことにする。そして，あるランドマーク の認識処理が終了したら，そのランドマークを観測したときか ら現在までに保持されたすべての位置情報を順々に修正しなが ら現在位置の修正を行うことにする。このようにすれば，現在 の位置情報は，これまでに処理が終了したランドマークの情報 をすべて反映した上で推定されていることになる.

このアルゴリズムは，二つ以上のランドマークの認識処理が 時間軸上で重なりあった場合においても同様である。

\section{6. 位置推定サブシステムの設計}

本章では，遡及的現在位置推定法を用いて位置を推定する， 独立したサブシステムとしての位置推定システムの設計方法に ついて述べる.

Fig.4 は，そのシステムの構成を示したものである。まず, 内界センサで測定されたロボット本体の速度・角速度を常に測 定しデッドレコニング法により位置情報を更新する機能を用意 する．そして，ランドマーク認識システムから提供される位嘈 情報を最尤推定法を用いてデッドレコニングと融合を行う機能 を用意する．また，ランドマーク認識システムからの認識処理 の開始・終了の指示に基づいて，邀及的現在位置推定に必要な データを管理する機能を用意する。このような機能を Fig. 4 に 示すように統合すると遡及的現在位置推定機能を有する位置推 定サブシステムが実現できる。

本位置推定システムは，ランドマーク認識システムからラン ドマーク認識の開始・終了, そして, その認識結果から得られ る位置情報などをコマンドとして入力すれば, ブラックボック スとして利用できる。 また，その出力である推定現在位置情報 は, 走行制御, 動作計画, そして, ランドマークの探索筙囲の 制限など様々な目的で他のサブシステムから利用できる。

次に，本設計方法に基づき，トランスピュータ T805を CPU

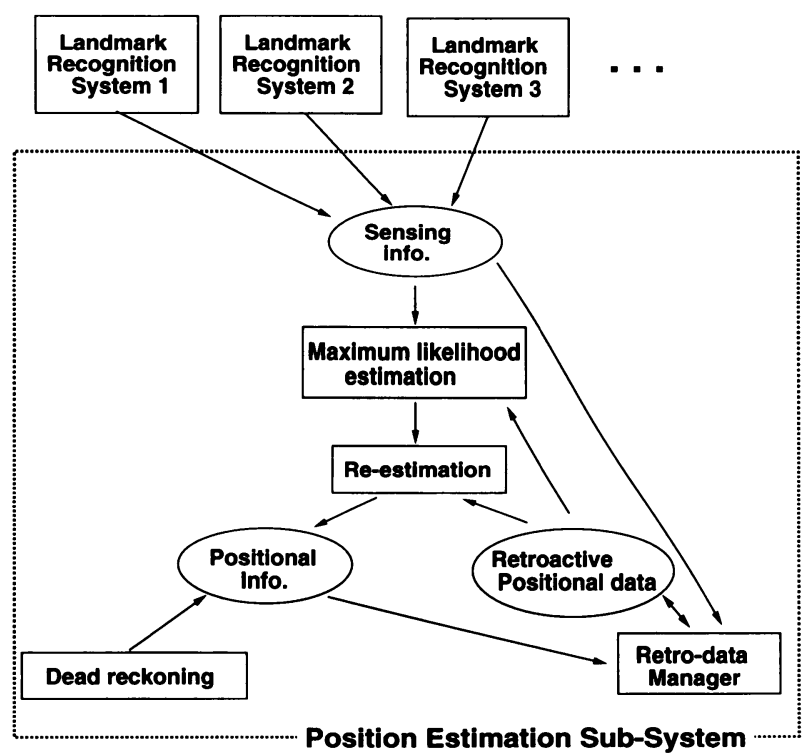

Fig. 4 Position estimation sub-system using retroactive positioning data fusion 
とするコントローラ上に独立した位置推定サブシステム POEM III を実装した[8]. POEM III では，デッドレコニングの計算 のためのサンプリング時間間隔 $\tau$ は, $5[\mathrm{~ms}]$ である．また，内 外界センサデータの融合と 4 章の公式を用いた遡及的再計算の 1 回分の計算時間は, 約 $1[\mathrm{~ms}]$ であった。デッドレコニングの 計算, コマンド入力の解析, 出力情報の提示などの他の計算に 要する時間を含めて, 総計算時間は, 約 $3.5[\mathrm{~ms}]$ であった。し たがって, 複数のランドマーク認識処理が時間軸上で多重に重 なり合う場合を除き，1 ステップのデッドレコニングのサンプリ ング間隔のなかですべての計算が行えるシステムが実現できた. また, POEM III をブラックボックスとして使うためのコマン ドとして, ランドマークの認識処理を開始したことを POEM III に伝えるコマンドやランドマークの認識処理結果を用いた 遡及的位置推定を要求するコマンドなどを用意した。

\section{7. 実 験}

筆者らが有する自律移動ロボット「山彦ナビ」に前述した POEM III を実装し, Fig. 5 に示す環境で通常速度 $(25[\mathrm{~cm} / \mathrm{s}])$ を落とさずに走行させる実験を行った。この環境では，木や生 け垣がランドマークとして利用できる。生け垣は, 超音波距離

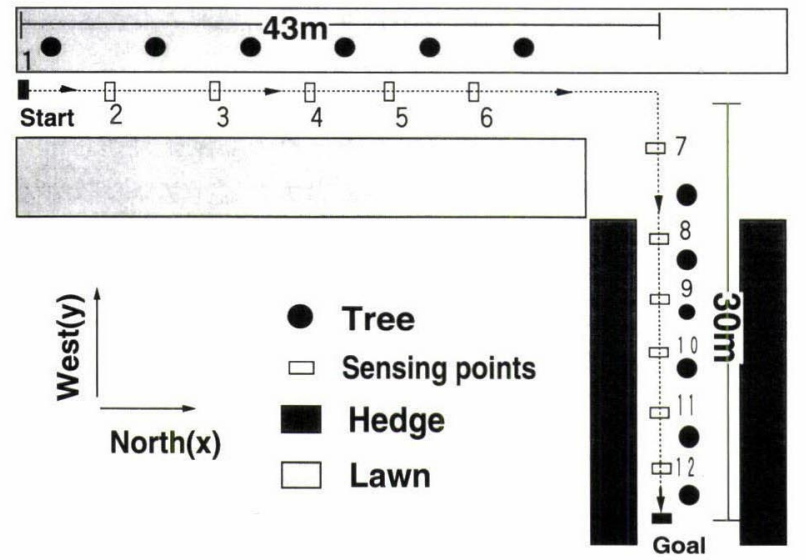

Fig. 5 Experimental environment for the non-stop self-guidance of the mobile robot using trees and hedges landmarks
センサを用いて瞬時に検出できるが，木の認識は，画像処理と 超音波距離センサの融合による街路樹検出センサ SONAVIS [5] を用いて検出するのに約 2 秒の処理時間を要する。また，これ らのランドマークの認識処理は, 独自の CPU を有する別々の モジュール上で並列に行われる。ロボットには，木や生け垣を ランドマークに利用して位置を推定しながら $43[\mathrm{~m}]$ 直進し右に 曲がって $30[\mathrm{~m}]$ 直進するという経路を走行させた. その結果の

一例を Fig. 6 に示す. Fig. 6 の合成画像は, 一定時間間隔の ロボットの画像を同じ背景の上に重ねたものである。これによ り，ロボットは，一定速度を保ちつつ走行していることが確認 できた。

次に、ロボットの内部で行われている計算の様子を示すため に，木と生け垣をランドマークに利用したナビゲーションの シミュレーション結果の一例を Fig. 7 に示す. Fig.7の (A) は，木を観測した時点でのロボットの位置情報を示している。 （C）は，木の認識処理中に生け垣による位置の修正を行ってい る様子を示しており，(B) は，木の認識処理が終わったときに， その処理結果を利用して木を観測した時点でのロボットの位置 情報を修正した結果である。そして，(E) は，木の認識処理が 終わったときに，その処理結果と生け垣による修正結果も含め て現在位置情報を修正した結果である。ただし，本シミュレー ションでは, 複数のランドマーク認識処理が時間軸上で重なり 合った場合の計算例を示すため，木の認識処理に要する時間を $10[\mathrm{~s}]$ にしている。 その点だけが実機実験と条件が異なる（C) は，木の認識処理時間中に生け垣を使った修正が行われ，その 結果ロボットの位置が修正され推定位置の精度が向上し, 誤差 棈円の大きさが縮小していることが分かる，その後生け垣が途 切れてから，再び，(D) のようにいったん䛊差楕円が増大する が木の認識処理が終了したことによって，木の認識処理開始時 の位置情報（A）が（B）に修正され，現在位置が途中の生け 坦による修正も考慮した上で $(\mathrm{E})$ のように修正されている。誤 差楕円 (E) がその一つ前の誤差楕円 (D) よりも小さいことは, 生け垣だけによる位置推定よりも生け垣と木の両方を用いた位 置推定のほうがより精度が高いことを示している。

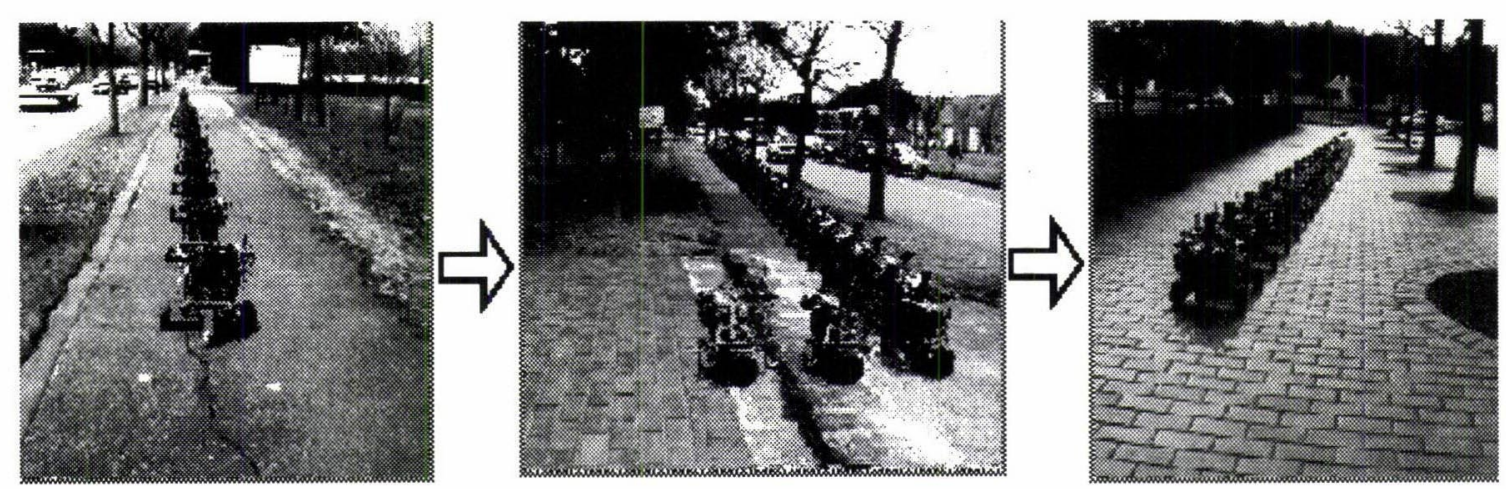

Fig. 6 Trajectory of a mobile robot on the experiment of non-stop self-guidance using trees and hedges 

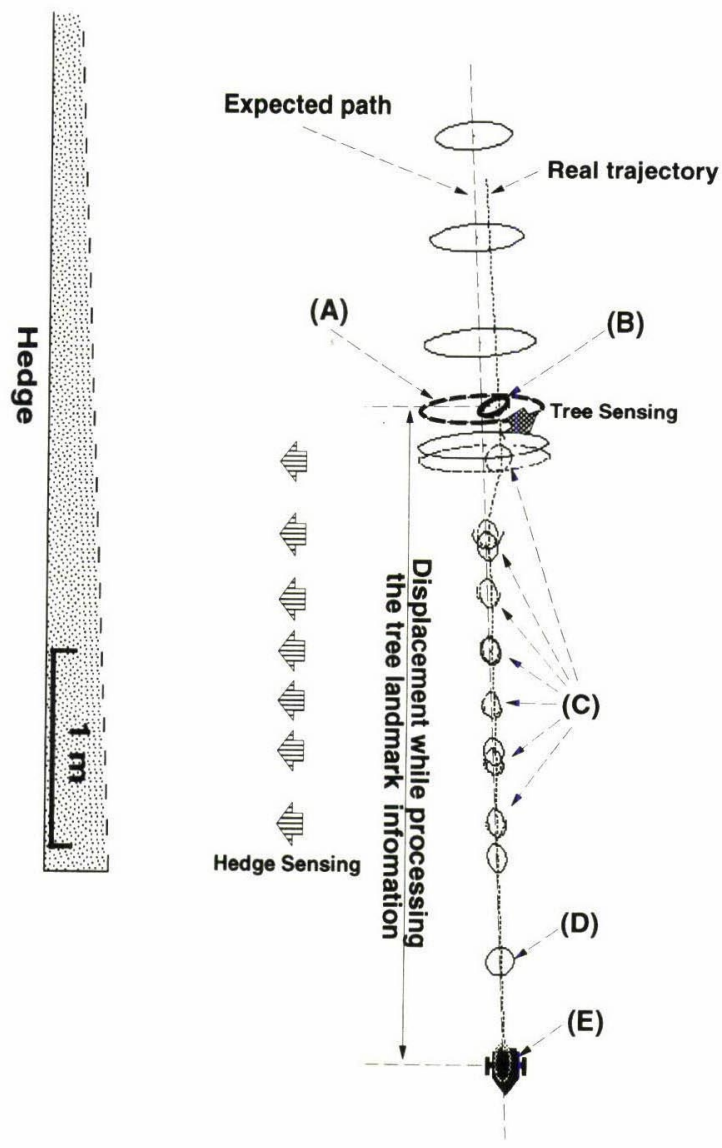

$\frac{1}{7}$

Fig. 7 Simulation result of the retroactive positioning data fusion using tree and hedge landmarks. (A) Positional uncertainty before fusing tree info. when tree is sensed, (B) After fusing tree info. when tree is sensed, (C) After fusing hedge info., (D) Before fusing tree info., (E) After fusing tree and hedge info.

\section{8. ま め}

本論文では, デッドレコニングとランドマーク認識の融合に よる位置推定における遡及的現在位置推定法を提案した. 本法
は，不確実性を考慮した複数センサ情報の融合において，各セ ンサの処理に要する時間の相違を考慮してセンサ融合するため の一手法である，本手法により，ランドマークの認識処理に時 間を要する場合においても，ロボットは通常の走行速度を維持 したまま走行できるようになった．本法は，ランドマークの観 測時刻の位置情報とその後の位置情報の増分だけを保持してお く.そして, ランドマークの認識処理が終了した時点で, 処理 を開始した時点の位置情報を修正し，次いで，現在位置情報が 修正できる，本法は，計算方法も比較的簡単であり，記憶すべ き容量も少ない.さらに, 本手法は, 複数のランドマークが時 間的に重なりあって処理される場合にも適用可能である.

\section{参 考 文 献}

[1] Y. Watanabe and S. Yuta: "Position Estimation of Mobile Robots with Internal and External Sensors Using Uncertainty Evolution Technique," Proceedings of IEEE International Conference on Robotics and Automation, vol.3, pp.2011-2016, 1990.

[2] J.J. Leonard and H.F. Durrant-whyte: "Mobile Robot Localization by Tracking Geometric Beacons," IEEE Transactions on Robotics and Automation, vol.7, no.3, pp.376-382, 1991.

[3] K. Komoriya, E. Oyama and K. Tani: "Planning of Landmark Measurement for the Navigation of a Mobile Robot," Proceedings of IEEE/RSJ International Conference on Intelligent Robots and Systems, vol.2, pp.1476-1481, 1992.

[4] K. Kimoto and S. Yuta: "Sonar Based Outdoor Navigation," Proceedings of International Conference on Advanced Robotics, pp.239-244, 1993.

[5] S. Maeyama, A. Ohya and S.Yuta: "Positioning by tree detection sensor and dead reckoning for outdoor navigation of a mobile robot," Proceedings of Int. conference on Multisensor Fusion and Integration for Intelligent systems, pp.653-660, 1994.

[6] A. Kosaka, M. Meng and A.C. Kak: "Vision Guided Mobile Robot Navigation Using Retroactive Updating of Position Uncertainty," Proceedings of IEEE International Conference on Robotics and Automation, vol.2 pp.1-7, 1993.

[7] 有本卓：カルマン・フィルター. 産業図書, 1977.

[8] S. Maeyama, A. Ohya and S. Yuta: "Non-stop outdoor navigation of a mobile robot - Retroactive positioning data fusion with a time consuming sensor system-," Proceedings of Int. conference on Intelligent Robots and Systems, vol.1, pp.130$135,1995$.

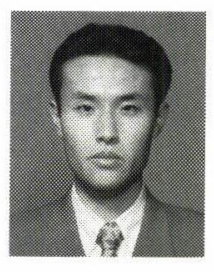

前山祥一（Shoichi Maeyama）

1971 年 2 月 10 日生. 1993 年 筑波大学第三学群情 報学類卒業. 現在, 同大学大学院博士課程工学研 究科在学中. 移動ロボットの屋外ナビゲーションの 研究に従事. ランドマークの認識および現在位置 の認識のための複数センサ情報の融合に興味を持 つ. (日本ロボット学会学生会員)

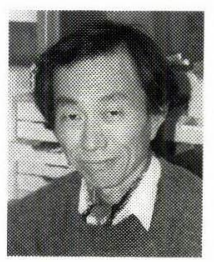

油田信一（Shin'ichi Yuta）

1948 年 3 月 23 日生. 1975 年慶應義塾大学大学院 (電気工学専攻) 修了. 工学博士. 現在筑波大学電 子情報工学系教授. 知能移動ロボット, ロボット センサ, ロボット用コントローラなどの研究に従 事. 自動制御や信号処理の理論と応用に興味を持 つ. IEEE, 計測自動制御学会などの会員.

(日本ロボット学会正会員)

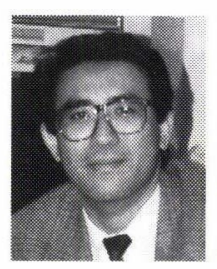

大矢晃久 (Akihisa Ohya)

1965 年 3 月 16 日生. 1992 年 慶應義塾大学大学院 理工学研究科電気工学専攻修了. 博士 (工学). 現 在, 筑波大学電子情報工学系講師. 1995 年 1996 年米国パデュー大学訪問研究員. 自立移動ロボット のためのセンシングシステムとその応用に関する 研究に従事. IEEE, 計測自動制御学会, 日本音柿 学会, 電子情報通信学会などの会員. 